\title{
Culture Conflict Between Moonshiners and the Government: An Explanation of Jury Nullification and Nolle Prosequi in Illicit Alcohol Offenses in Rural Communities
}

Egan K. Green, Ph.D.

Department of Criminal Justice

Radford University

P.O. Box 6934

Radford, VA 24162

Corresponding author: Egan Green, 540-831-5995; ekgreen@radford.edu

\begin{abstract}
The distillation, distribution and use of illicit alcohol have historically been widely accepted in many rural communities. A conflict has long existed between this community acceptance and the law. As a result, agents attempting to enforce alcohol violations pertaining to moonshine have historically been frustrated by their inability to gather posses, find witnesses and win convictions in court. This article uses data collected from qualitative interviews to examine how this social acceptance of illegal behavior has contributed to this frustration and demonstrates how cultural conflict explains why prosecutors decline to prosecute defendants for criminal offenses, an act commonly referred to in legal circles as nolle prosequi decisions, as well as examples of jury nullification.
\end{abstract}

Keywords: nolle prosequi, illicit alcohol, conflict theory, community acceptance 


\section{Introduction}

The practices of jury nullification and nolle prosequi, whereby a prosecutor refuses to file criminal charges for a possible crime, are controversial and can contribute to public disillusionment toward the criminal justice system. However, they may also provide justice in the view of some communities, particularly when the community members believe law enforcement practices, or the law itself is unjust. These events provide a glimpse of Sellin's (1938) argument that some crimes are manifestations of cultural conflict between localized expressions of norms and values and those of the dominant culture and the imposition of laws through the state. This appears to be particularly true in rural areas where folk crimes are accepted by community members regardless of how the law views them (Forsyth and Marckese 1993; Wilson1983; Bertrand and Baird 1975).

This article presents research from qualitative interviews with participants involved in the industry of illicit alcohol, commonly referred to as moonshine or white lightning. The sample includes producers (referred to as moonshiners), consumers, and traffickers (referred to as bootleggers), as well as retired alcohol law enforcement officers. The interviews reveal evidence of jury nullification and nolle prosequi in rural areas of the United States in regards to crimes involving moonshine. It is proposed here that public acceptance of moonshine production, use and trafficking makes illicit alcohol offenses involving moonshine a folk crime according to the definition that Forsyth and Marckese (1993) use. This definition notes social acceptance in rural areas of some behaviors that are illegal. For the current research, this acceptance is manifested through jury nullifications and prosecutor refusals to file charges. The qualitative data provides evidence of both of these legal phenomena. These moonshine related offenses appear to demonstrate how rural American culture conflicts with alcohol restrictions imposed by state and federal governments, thereby providing an example of Sellin's (1938) "Cultural Conflict" explanation of crime. His article also provides an explanation and overview of the concept of folk crime and explains how the data support these concepts by asserting that jury nullification and nolle prosequi practices reflect folk crime and that these practices are examples of Sellin's Cultural Conflict explanation.

\section{Review of the Literature}

This article links the illegal behavior associated with moonshining with criminological theory issues of culture conflict theory and folk crimes as well as criminal justice system issues. Therefore, the literature for the pertinent issues is covered here, beginning with a discussion of the scant research on moonshining. 


\section{Literature on Moonshine}

The field of criminology has overlooked the deviance surrounding the illegal production, trafficking and use of illicit alcohol. Literature on this subject is typically in the form of books that are not centered on criminological issues. For example, Miller's (1991) analysis of moonshine markets in southern states during the post-bellum era is primarily an historical review. Other historical reviews with a cultural special interest emphasis are provided by Greer (2004), Carr (1971), and Wigginton (1971). Watman (2010) presents a log of modern attempts to distill moonshine along with historical insights into the practice of moonshining.

Academic articles on moonshining reflect a wide-range of disciplines from fields other than criminology. Academic research on moonshining practices has been published in the areas of Appalachian cultural research (Peine and Schaft 2012), history (Guthrie Jr. 1994; Rayburn 1957), archeology (Douglas2001) and marginally in economics (Spellman and Jorgenson 1982). While all these sources refer openly to the illegal nature of illicit alcohol production, trafficking and use, none of them come from the field of criminology. Like many rural crime issues, criminologists have simply not explored this area of research. This article sets out to address this shortcoming by noting the connection between this form of deviance and a criminological theory known as culture conflict and specific criminal justice issues, specifically jury nullification and nolle prosequi decisions.

\section{Literature on Culture Conflict Theory}

Thorsten Sellin (1938) presented the culture conflict explanation of crime. This theory states that groups, especially subcultural groups, place expected behaviors, called conduct norms, on its group members. Members of these subcultures are indoctrinated into the accepted behaviors through socialization. Under certain circumstances, these subcultural conduct norms violate the formal controls of their dominant cultures. He states, "[I]t is necessary to think of culture conflict as a conflict of conduct norms, that such conflict may arise as a result of a process of group differentiation within a cultural system or area, or as a result of contact between norms drawn from different cultural systems or areas..." (Sellin1938, p. 98).

Sellin's (1938) primary example of this theory focused on immigrant groups that had been entering the United States in the decades preceding and simultaneous to his writing. As these groups brought the accepted norms of their immigrant subcultures into the existing American culture and followed those conduct norms, they sometimes found themselves in violation of U.S. laws. This was defined as primary cultural conflict whereby the conduct norms of a new, subordinate group conflict with the existing, dominant group. However, it is important to note that these were not the only conditions of culture conflict that Sellin addressed. He also proposed cultural clashes between rural and urban conduct norms. This was propositioned to be a growing concern as America urbanized. This secondary culture conflict occurs when, "[S]egments within the same culture differ as to the acceptability of conduct norms. In other words, one social group 
defines something as deviant or criminal, yet others in the same culture consider this behavior normal and noncriminal" (Lanier, Henry and Anastasia, 2015, p. 196). It is this secondary culture conflict that is most relevant to the current discussion. The distinctions between rural and urban cultures highlight the explanations for why illicit alcohol production is accepted in some rural communities yet prohibited by the dominant culture's law.

Einat and Herzog (2011) propose that culture conflict can be seen in terms of perceptions of seriousness of criminal offenses. In their sample, different subcultures rated the seriousness of offenses differently. The current study follows the same rationale in asserting that some rural subcultures view moonshine offenses as less serious than the dominant cultural view that makes it illegal. Hence, because making, drinking and trafficking moonshine is accepted by a rural community while the dominant culture prohibits it through law, it serves as an example of conflicting norms. The community acceptance would therefore make involvement in the moonshine trade a folk crime, as explained below. This should manifest itself in the criminal justice system through cases of jury nullification or prosecutor refusals to prosecute out of concern for disrupting the typically accepted behavior of a rural community.

This study proposes that juries from moonshine-accepting communities will demonstrate their acceptance of the behavior by failing to convict offenders despite the strength of the evidence in their cases. It also proposes that prosecutors in moonshine-accepting communities will refuse to prosecute some moonshine cases. This may be due to either a belief that a conviction is unlikely, or a concern that reelection chances are diminished by prosecuting a case for a socially accepted behavior. Regardless, both results derive from community acceptance of the behavior.

\section{Folk Crime Literature}

The concept of folk crime refers to acts that meet the legal definition of illegal acts but are accepted by the community where the acts occur and are therefore treated with indifference. Wilson (1983, p. 123) defines folk crime as, "offenses that do not impair the public identity of offenders as respectable, law-abiding citizens." Ross (1960-1961) provides an example in traffic offenses and asserts that folk crime offenses are not stigmatized in society because they are considered less severe than other offenses. This is augmented by the fact that many offenses do not require the intent element and are mala prohibita offenses, that is, actions made illegal as a result of legislative action or governmental regulations but are not considered wrong in and of themselves. Thus, they are not viewed as nefarious when they are stand-alone offenses. However, this is not to imply that all folk crimes are minor offenses in terms of the law's definition of the behavior, only that social mores may be accepting of the behavior regardless of the legal view of it. Furthermore, some of this may be the result of new laws infringing on previously established standards of conduct. New laws often have a "lack of basis...in traditional morality" (Ross, 1973, p. 80). 
Folk crime has been recognized by researchers for a number of acts and appears to be particularly relevant to some rural-specific offenses. When societies become more complex as a result of expanded industrialization, traditional rural values often conflict with new value systems that expand into rural areas. Therefore, previously accepted behaviors may become illegal, but rural residents will still subscribe to the previously held beliefs. As Forsyth and Marckese (1993, p. 27) state, "They are oriented toward the past, remain(ing) isolated pockets of traditionalism and are in conflict with the codes of the larger culture." Therefore, some rural offenses appear to serve as examples of folk crimes.

Researchers have noted a number of offenses that have been classified as folk crimes. Ross (1960-1961, 1973) explains folk crime in the context of motor traffic violations in the midtwentieth century as driving skills were new and developing rapidly. Indeed, even modern violators of minor traffic laws do not lose social status in their communities as a result of their offenses. Bertrand and Baird (1975) note that burning forests was once accepted as a means of clearing timber from a stretch of land and therefore accepted by rural communities. However, this type of burning was criminalized in the twentieth century, yet rural community views did not simultaneously change, so burning woods was not condemned in many rural communities even after the behavior had been outlawed. Wilson (1983) found that law enforcers actually made accommodations for shell fishermen who violated the law through their interpretation of the law and the offenses because local communities were tolerant of the violations. Forsyth and Marckese (1993) sampled poachers in Louisiana and concluded that folk crime explanations are relevant to their behavior because of the social acceptance in the rural areas where poaching occurs. In further research on game violations, Forsyth (2008) further explains illegal hunting as a form of folk crime.

Gibbons (1972) notes the quantity of non-serious offenses in rural areas including a high number of alcohol related offenses. He also describes many rural offenses similarly to folk crimes, but he dismisses the associational nature of the offenses. This is a departure from the majority of folk crime discussions. Folk crimes do not result in the loss of social status for offenders, but the social acceptance of the community is still related to the nature of associations in the rural setting. This is an important note in that social relationships with offenders and acceptance of their behaviors seems to contribute to jury nullification.

\section{Jury Nullification Research}

Jury nullification is somewhat unique to the American criminal justice system. Horowtiz, Kerr, Park and Gockel (2006, p. 163) define it as "[T] he power of jurors to return verdicts that are counter to both the law and the evidence." When a jury exercises this unofficial power, it renders a not guilty verdict despite solid evidence pointing to a defendant's guilt. This has the effect of negating a law for that particular case. Jurors have this ability because they are not required to provide explanations for their decisions and jury deliberations are kept confidential. The reason for a jury acquittal may be for completely legitimate reasons, such as a lack of belief 
in the defendant's guilt. However, nullification is often the result of a community's unwillingness to convict one of its members for an offense because there is either no public support for the law that is being enforced or the way it was enforced, or incredulousness toward law enforcement officers who may not be from the community. Ullman (205, p. 1097) states, "[T] he secretive nature of deliberations allows jury members to acquit for any number of nonevidentiary reasons, such as sympathy for the defendant or personal displeasure with the law under which the defendant is charged."

Because jury nullification is not an official verdict, some interpretation and judgment is required to determine whether it has occurred when an acquittal is presented. With that caveat, there is reason to believe that jury nullification is not widespread (Hannaford-Agor and Hans 2003) but some cases seem to draw its use most frequently. Scholars have noted its use in cases involving three strikes laws, mandatory sentences, assisted suicide, drug possession, firearms charges (King 1998), draft resistance, escaped slaves and prohibition enforcement (Ullman, 2005). Miller (1991) notes the difficulty of alcohol enforcement, including winning convictions in southern jurisdictions during the decades following the Civil War. Okrent (2011) observes that during the prohibition era public resistance to alcohol laws was so strong that jury nullification for alcohol offenses was commonplace; he even refers to the public reaction to anti-alcohol laws as "social nullification". This history of social acceptance of alcohol despite the law's limitations is particularly relevant to this paper even though the data refer to a period of time decades after prohibition.

\section{Literature on Prosecutor Discretion}

Local jurisdictions' prosecutors may also have their discretion influenced by their communities' unfavorable view of particular laws. Prosecutors may refuse to seek charges against a defendant for a legitimate reason such as a belief that the evidence is too weak to win a conviction, or that police procedures were improper and may therefore result in an acquittal if the case were brought to trial. Problems resulting from pursuing criminal charges despite these problems are complicated by the double jeopardy protection; if the prosecutor tries to force a case through the court system despite evidentiary or procedural problems, the problem will never be eligible for a legal fix if the trial results in an acquittal. Therefore, prosecutor discretion is a necessary element of the criminal justice system, but like all forms of discretion, it presents the opportunity for abuse. Concerns occasionally arise that prosecutors decide to refuse to prosecute cases (a process referred to as nolle prosequi) based on extra-legal factors.

In noting the contentious nature of this power, Adams and Cutshall (1987, p. 596) state, "Discretionary use of the (nolle prosequi) as a final case disposition can be controversial because this action precludes the possibility of conviction." Their research concluded that legal factors were the best predictors of nolle prosequi decisions, but that other factors also played a role in the handling of minor cases. Nuebaur and Fradella (2011) explain the complex nature of prosecutorial discretion in terms of prosecutors' legal judgments, their policy priorities and their 
own standards of justice. After reviewing the literature, they conclude similarly to Adams and Cutshall (1987) that in the realm of legal judgments, sufficiency and strength of evidence is the primary reason for prosecution. However, other reasons they cite are beneficial for understanding the current research. In the case of policy priorities, prosecutors may refuse to pursue criminal charges in cases with relatively minor charges or when the behavior is not a threat to the community. Given limited resources, prosecutors often pursue charges in the most serious cases thereby demonstrating their concerns for those cases at the expense of prosecuting less serious offenses. Neubauer and Fradella (2011) also note that personal standards of justice can influence whether a case is prosecuted. If the prosecutor does not believe the criminal behavior creates a threat to the community, regardless of the strength of the evidence, he or she may refuse to file charges. Therefore, prosecutors may not pursue criminal charges (nolle prosequi) after legitimate arrests due to concern that enforcing an unpopular law may have negative political ramifications.

The interview data provided in this research project indicate that charges in rural communities are often not filed or are dropped after they are filed. Because prosecutors do not have to provide explanations for their refusal to file charges, it is difficult to conclude the reasons the cases referenced by this study's informants were nolle prossed. However, as the interview data below demonstrate, the study participants attribute the reasons to prosecutors' concerns about legal matters such as whether a conviction could be won, as well as extra-legal matters such as personal standards of justice in communities where moonshine involvement was fairly typical.

\section{Methods}

This research used qualitative interviews with participants who had previous involvement in the illegal liquor trade. This data collection method is appropriate for this research for a number of reasons. Because criminological research has not previously been done on moonshine violators, this research is exploratory. Berg (2004) notes the utility of collecting qualitative data for exploratory research. Furthermore, the participants were older men who were comfortable carrying on conversations about their actions to an acquaintance, but would not take the time to answer a survey. They were willing to provide in-depth explanations during conversations, but would not take the time to write out their answers. Additionally, the qualitative interview allowed the researcher to ask follow up questions and seek clarification. This research method has been used to study a variety of sensitive topics including marijuana and other drug usage (Hallstone 2006), marijuana cultivation (Hammersvik, Sandberg and Pedersen 2012; Riggs, Hafley and Tewksbury 1996; Weisheit 1990),methamphetamine usage (Daniulaityte, Carlson and Kenne2007), pharmaceutical opioid abuse (Daniulaityte, Carlson and Kenne 2006), human sex trafficking (Troshynski and Blank 2008) and alcohol consumption among young American adults (Antin, Paschall and Nygaard 2010) and citizens of India (Gaunekar, et al. 2004). Additionally, previous research on moonshining has used the qualitative interview method (Peine 
and Schaft 2012; Wigginton 1971). This history validates the utility of this method of data collection for this type of research.

This research project's sample was obtained through snowball sampling. It began with participants known to the researcher who had a history of involvement in making, drinking or trafficking in illegal liquor and grew as acquaintances gave the researcher access to other participants. This sampling method is commonly used to access otherwise "impenetrable social groupings" (Atkinson and Flint 2001). It has been used in researching sensitive issues involving prostitutes (McNamara 1994), drug users (Avico, et al 1998; Kaplan et al 1987), and pickpockets (Inciardi 1977).

The sample includes violators as well as law enforcement officers. Additionally, the sample includes a participant who was a newspaper reporter for a paper in a rural community with a high amount of involvement in the alcohol trade. The interviews were designed as semi-formal interviews whereby the participants were asked a series of questions about the moonshine market, involvement and social dynamics surrounding the market. However, these questions were only used as a guide; the data gathered for this project were largely the result of an unforeseen consistency that emerged during the conversations with a number of participants.

The sample is composed of nine participants who admit to a history of making, drinking and/or selling and transporting moonshine. All of these participants self-report their deviant behavior, but only in the past tense; they all stated that they had once been involved in the illicit alcohol industry, but had not been involved in it for several years. According to the dates they provided, this year range extends from the 1940s into the 1990s.

The sample is also composed of six retired law enforcement officers who had experience enforcing laws pertinent to the moonshine industry. The majority of the officers were employed by agencies specifically geared toward the enforcement of alcohol laws such as the Bureau of Alcohol, Tobacco and Firearms or state alcohol enforcement agencies. However, one of the retired law enforcement officer participants was a retired state trooper who primarily enforced traffic violations. The majority of his career was spent working in a rural, Appalachian county where the moonshine market was quite active. As a result, he was often involved in high-speed chases with bootleggers. Another retired law enforcement officer was a sheriff from a rural Appalachian county. One other officer retired from his job as a game warden for the state of Kentucky. In carrying out his official duties, he was often in the forests enforcing wildlife laws. However, this time in the woods often put him in contact with moonshiners or their still sites. Additionally, he grew up in the Appalachian mountains of Kentucky so he was familiar with the moonshine culture in the region. These officers primarily worked from the 1970s into the 1990s, however, some of them worked as far back as the 1950s.

One other participant was a retired newspaper reporter who worked in a rural Appalachian community that had a high volume of illicit alcohol traffic. His involvement was as an observer 
who neither enforced the law nor took part in the industry. During his career he had written a number of news stories about illicit alcohol cases. In carrying out this job, he had interviewed many moonshiners and bootleggers. He had also interviewed numerous law enforcement officials about illicit liquor violations. His data proved helpful because they provide community context from a neutral observer of the market.

All of the participants were white males. Their ages ranged from the mid-50s to a participant who was in his 80s. Exact ages were not asked as part of the researcher's effort to guarantee anonymity. The portion of the sample composed of moonshiners came from rural, Appalachian Mountain communities in North Carolina and Virginia. All of the law enforcement officers had worked most or all of their careers in Appalachian communities.

The participants were guaranteed confidentiality, although some were guaranteed anonymity because the researcher was only given access to them through a trusted contact; this only happened with participants in the illicit alcohol production business. In those cases, the researcher was not given the names of the participants. The participants' responses were written down at the time of the interviews and reviewed for clarification as soon after interview conclusions as possible. Most of the interviews were carried out at the residences of the participants, however, one moonshine producer was interviewed at a public location and two of the retired law enforcement officers were interviewed in a restaurant.

\section{Results from the Interview Data}

The interviews provide clear-cut examples of jury nullification and nolle prosequi in moonshine cases.

\section{Jury Nullification}

The interview data point to the commonplace acceptance of moonshine in the participants' jurisdictions. This explains why winning convictions for illicit alcohol violations was so challenging. One admitted user answered with the following quotation when asked about how concerned he was about law enforcement catching him with illicit liquor.

"I'm pretty discreet about it. I never bought in bulk. I never bought enough to be concerned about it. I just don't think a jury would be willing to put me away for buying a little at a time."

Another participant from another state provided this quote pointing to a belief based on previous knowledge that social acceptance would prevent some forms of moonshine production from resulting in convictions.

"Some people just make it for themselves or for their family. They can't convict you for that if you're not selling it no matter what the law says. People around here just won't allow it. The jury would let them walk just like lots of others already." 
In the following statements, two retired BATF agents support this belief in explaining the frustrations of filing illicit alcohol violation cases in two Virginia counties.

"It didn't matter how strong the evidence was for cases in county. They just weren't going to convict."

"Everyone in that county was in it in some way. Some were making it, some were selling it and everyone was using it. They all had family members involved somehow. So even if it wasn't their family member for a case where they're a juror, it was going to be a neighbor or something. So they just weren't about to convict someone for a moonshine case."

Another law enforcement officer explained the frustration of seeing a defendant acquitted despite strong evidence.

“The jury just thought I was an outsider. The evidence just didn't matter. They saw me as an outsider from the city and if their neighbor said he didn't do it, then he didn't do it no matter how strong the case was."

"They saw me as an outsider and he was one of them. They just decided I was just making it all up I guess."

Another retired officer reiterated this frustration with illicit alcohol cases with the following quotes.

“They just weren't going to convict some of these guys. Some jurors had actually bought liquor from the defendant. Of course, they knew he made it. They just weren't going to convict their own friend."

"I had the guy dead to rights, but the jurors trusted their neighbors over me."

"They just didn't believe me. Thought I was lying."

One officer interpreted the jurors' actions by mimicking the jurors' thought process. The following quotations are the officer's sarcastic interpretation of the jurors' opinions in multiple moonshine cases.

"These big city sons of bitches come in here trying to tell us our business."

"They don't know any better than us how to make a living."

Judging from the following quotes from one informant, one community's propensity toward jury nullification extended to at least one grand jury.

"The grand jury didn't indict him...He had everything there at the still and was working it, but he didn't have any liquor at the site...It hadn't run yet... It sounds like the grand jury was just looking for a reason not to indict him." 
The refusal to indict even extended to a retired sheriff who would give small portions of the illicitly produced liquor to local residents who came seeking it to make home remedies.

"We would give 'em some if they came in the office and were sick or told us that one of their kin was sick. We didn't give 'em much, just enough to make syrup or an elixir. But the state found out and tried to have me indicted more than once for trafficking in it, but the grand jury never would indict me...I ended up getting my picture in Time magazine about the whole thing."

It is important to note that many of these examples refer to different counties. This suggests that moonshine had a ubiquitous presence in many areas during the mid to late twentieth century and that those communities were largely tolerant of it.

\section{Nolle Prosequi}

Self-reported moonshiners provided the following quotations suggesting that nolle prosequi was also a common practice in their counties from the 1950s into the 1990s. It is evident that in some cases the respondents believed their local criminal justice systems were influenced by the commonplace involvement of much of the community in the illicit alcohol industry. In at least one event, a moonshine producer believed his case was not prosecuted because of a secondary connection to a judge.

"Well, I knew that I'd been selling liquor to a man who was getting it for the judge. So I figure (the prosecutor) knew that if he charged me, it wasn't going to do him no good. So, he just dropped the charges."

Another participant referred to a similar event. Because he did not refer to his subject by name, it is not known whether the following quotation refers to the previous quotations' event.

“There's a guy who was making the judge's whiskey when he got busted, but it ended up getting thrown out (of court). I don't know why, but you can guess."

Other self-reported producers reported a lack of concern about suffering legal consequences for their action and attribute this attitude to community favorability to moonshine involvement.

"I don't worry about getting caught. Even if they catch me, they won't be able to make it stick in court. There's too much public against them... They aint gonna do nothing to (me)."

"Well, everybody around here does it. Where they gonna find a jury that'll convict me or anybody else? They're better off just dropping the charges most of the time."

Retired BATF agents provided the following quotations which also to demonstrate prosecutors' refusals to file charges against defendants of moonshine cases. 
"We finally just started going to federal court because going to state court would have been useless. The (prosecutor) just wouldn't file the charges."

"I went to court lots of times and found the courtroom empty and the lights out...The prosecutor would just nolle prosequi the case and wouldn't even bother to tell us."

"You weren't going to get reelected in county if you started prosecuting moonshiners. There were just too many people making money off it around there."

"It was so common down there that one time I found out that the sheriff's office had run my tags after I had been on a stake out. (The moonshiners) spotted my car I guess and had connections with the sheriff's office, so they ran it. After that, they stopped doing anything... When it's that entrenched in a community, you're just not going to be able to get a prosecutor to bring a lot of charges."

A retired sheriff felt that moonshine use and trafficking was so common in his jurisdiction that he eventually stopped putting serious enforcement efforts into it.

"Everyone around here had just accepted it as a part of life. It was so hard to get convictions that we finally just started confiscating the liquor without charging them. We would still confiscate it, just not charge "em."

Another retired officer reiterated the belief that politics influenced the prosecution decision in another county where the moonshine industry was active.

"If everyone in the county is drinking it or making it, then it's part of the economy. Especially when there's no other jobs around there. The (prosecutor) knows that and isn't about to risk his job for something that is a part of their everyday life."

One resident who was a longtime witness to moonshine events in his county provided another example from one specific case in which a geriatric veteran had been raided at his still site. The language he uses provides examples of the reasons Neubauer and Fradella (2011) outline explaining why prosecutors often do not pursue charges.

"I don't think the prosecutor's office is going to file the charges... The community is on (the defendant's) side...An old guy like that, a veteran, and they raid him with their guns drawn. He's an old man and he didn't have a gun on him... The prosecutor has more important cases to worry about."

"The community's pretty upset." 


\section{Discussion}

The informal controls in rural communities often conflict with the controls of the state. Sellin (1938) noted this in explaining his Culture Conflict theory of crime. It is clear from the study participants' quotations that the rural communities where illicit alcohol was openly accepted had different definitions of acceptable behavior than the law had defined. Other interview data from the participants did not refer to the specific examples of jury nullification or nolle prosequi discussed here, but highlighted the belief that moonshine production and use was a ubiquitous part of life in those communities. For example, a retired alcohol enforcement officer told the researcher that confiscated alcohol was supposed to be destroyed within ten days of a conviction. Instead many of the sheriffs gave it to the voters. On another occasion that same officer caught a previously convicted moonshiner giving a jar to illicit liquor to a sheriff. The commonplace use of moonshine in the districts discussed here support the assertion that communities, including locally elected officials of the criminal justice system, accepted its use as a norm. The retired game warden stated that it was a part of the community culture in many rural areas to the point that interference in it caused more problems for the communities than allowing it to continue undisturbed.

The history of illicit alcohol production and its use in some rural areas of the United States suggests that the accepting culture is deeply ingrained and has not been deterred by longestablished laws. In fact, national prohibition from the 1920 s, nearly a century ago, may have reinforced many communities' views about the acceptability of moonshine, thereby solidifying its folk crime status. As Ross (1960-1961, p. 237) suggests, social acceptance of folk crimes may occur when there is a "lack of congruence between the new laws and established mores." Social approval of the illicit alcohol industry likely increased because prohibition seems to have increased economic vitality in some rural communities with a pre-existing history and culture or moonshine production. The moonshine production skills became more profitable as a result of prohibition, which reinforced the communities' positive views of the industry. Even after prohibition was repealed, the industry still thrived. One participant explained that national prohibition made only illegal liquor, which was primarily moonshine in some rural communities, available to drinkers. He stated, "They developed a taste for it. When the government stuff came back, it was too late. They already had the taste for moonshine". Furthermore, after national prohibition was repealed, some states instituted state-level laws prohibiting alcohol. The same participant stated that the networks for trafficking in illegal liquor had already been put in place by national prohibition. It was then only a matter of delivering the illegal liquor to the residents in the states that were still dry. Therefore, the market for illegal liquor continued years after prohibition was repealed.

This long history of social acceptance of moonshine made it more difficult to win convictions in these communities. The interviews delved into information that explains this but is illusive with other methods of data collection. For example, jury nullifications are not entered into official court records as such; they are only recorded as acquittals. The reasons for a jury to 
refuse to indict or convict a defendant do not have to be explained in any public forum. The same is somewhat true for prosecutor refusals to convict. Because prosecutors are given the discretion to determine which cases they believe merit legal pursuit, they make the decisions, but they do not have to enter their reasons into official court documentation. Therefore, the interviews discussed here provide insight into the participants' views of these legal actions. Furthermore, the interviews demonstrate that law enforcement officers and offenders from moonshine friendly communities independently believe that social acceptance of illegal alcohol behavior influences a prosecutor's ability to win a case in those jurisdictions.

The concept of grand jury nullification among this sample is also noteworthy. Grand juries have the ability to decide whether enough evidence exists to charge a suspect; the trial jury makes decisions about guilt or innocence. The grand jury proceedings tend to favor prosecutors. Therefore, if a grand jury from a community is unwilling to even indict a suspect based on the evidence and proceedings that favor prosecutors, a conviction in a criminal trial is unlikely. Similar to jury nullifications from trial juries, there is no official reason provided in court paperwork to indicate why a grand jury declines to indict a suspect, so data such as this can provide insight into the motivations for those decisions. The data here suggest that communities accepting of involvement in the moonshine trade are willing to nullify the law even in proceedings prior to criminal trials. This unique type of jury nullification, particularly in rural areas where norm may conflict with official laws, merits further research.

\section{Conclusion}

Social approval of the illicit alcohol industry in some rural communities has existed for centuries. Miller (1991), points out that many isolated communities historically went to great efforts to protect, conceal or defend moonshiners from revenue agents. The history of moonshine, as well as the interview data provided here point to evidence of Sellin's (1938) Culture Conflict theory in that some rural American subcultures have long been accepting and even expecting of behaviors that conflict with the larger culture's laws dealing with moonshine. Furthermore, Ross' (1960-1961) explanation of folk crime is used here to support this explanation by noting that there appears to be limited social condemnation or loss of social status associated with involvement in moonshine production and use in the communities discussed here. The interview data also demonstrate that jury nullifications, by petit juries as well as grand juries, and nolle prosequi decisions appear to be manifestations of Culture Conflict and folk crime status for moonshine related offenses in communities accepting of the illicit alcohol industry. 


\section{References}

Adams, K. and Cutshall, C.R. (1987). Refusing to prosecute minor offenses: The relative influence of legal and extralegal factors. Justice Quarterly, 4, 595-609, http://dx.doi.org/10.1080/07418828700089541

Antin, T.M.J., Paschall, M.J. and Nygaard, P. (2010). Process versus outcome-oriented drinking: An exploratory study of wine and moderate drinking occasions among young adults in California. Contemporary Drug Problems, 37, 241-266, http://dx.doi.org/10.1177/009145091003700204

Atkinson, R. and Flint, J. (2001). Accessing hidden and hard-to-reach populations: Snowball research strategies. Social Research Update, 33. Surrey, United Kingdom: University of Surrey.

Avico, U., Kaplan, C., Korczak D. and Van Meter, K. (1988). Cocaine Epidemiology in Three European Community Cities: A Pilot Study Using a Snowball Sampling Methodology. Rotterdam: Erasmus University, European Addiction Research Institute.

Berg, B.L. (2004). Qualitative Research Methods for the Social Sciences $\left(5^{\text {th }}\right.$ Ed.). New York: Allyn and Bacon Publishers.

Bertrand, A.L. and Baird, A. W. (1975). Incendiarism in Southern forests: A decade of sociological research. Washington, D.C.: United States Department of Agriculture

Carr, J. (1972). The Second Oldest Profession: An Informal History of Moonshining in America. Englewood Cliffs, N.J.: Prentice-Hall.

Daniulaityte, R., Carlson, R.G., and Kenne, D.R. (2006). Initiation to pharmaceutical opioids and patterns of misuse: Preliminary qualitative findings obtained by the Ohio Substance Abuse Monitoring Network. The Journal of Drug Issues, 36, 787-808, http://dx.doi.org/10.1177/002204260603600402

Daniulaityte, R., Carlson, R.G., Kenne, D.R. (2007). Methamphetamine use in Dayton, Ohio: Preliminary Findings from the Ohio Substance Abuse Monitoring Network. Journal of Psychoactive Drugs, 39, 211-221, http://dx.doi.org/10.1080/02791072.2007.10400607

Douglas, J.C. (2001). Miners and moonshiners: Historical industrial uses of Tennessee caves. Midcontinental Journal of Archaeology, 26, 251-267.

Einat, T. and Hezog, S. (2011). A New Perspective for delinquency: Culture conflict measured by seriousness perceptions. International Journal of Offender Therapy and Comparative Criminology, 55, 1072-1095, http://dx.doi.org/10.1177/0306624X10380553 
Forsyth, C.J. (2008). The game or wardens and poachers. Southern rural sociology, 23, 43-53.

Forsyth, C.J. and Marckese, T.A. (1993). Folk outlaws: Vocabularies of motives. International Review of Modern Sociology, 23, 17-31.

Gaunekar, G., Patel, V., Jacob, K.S., Vankar, G., Mohan, D., Rane, A., Prasad, S., Johari, N. and Chopra, A. (2004). Drinking patterns of hazardous drinkers: A multicenter study in India. In Haworth, A. \& Simpson, R. (eds.) Moonshine Markets: Issues in Unrecorded Alcohol Beverage Production and Consumption (pp 125-144). East Sussex, Great Britain: BrunnerRoutledgand.

Gibbons, D.C. (1972). Crime in the hinterland. Criminology, 10, 117-191, http://dx.doi.org/10.1111/j.1745-9125.1972.tb00552.x

Greer, T.K. (2004). The Great Moonshine Conspiracy Trial of 1935. Rocky Mount, VA: History House Press.

Guthrie, J.J. (1994). Hard times, hard liquor, and hard luck: Selective enforcement of prohibition in north Florida, 1928-1933. The Florida Historical Quarterly, 72, 435-452.

Hallstone, M. (2006). An exploratory investigation of marijuana and other drug careers. Journal of Psychoactive Drugs, 38, 65-75, http://dx.doi.org/10.1080/02791072.2006.10399829

Hannaford-Agor, P. and Hans, V.P. (2003). Nullification at work? A glimpse from the National Center for State Courts Study of Hung Juries. Dept. of Justice

Hammersvik, E., Sandberg, S. and Pedersen, W. (2012). Why small-scale cannabis growers stay small: Five mechanisms that prevent small-scale growers from going large scale. International journal of drug policy, 23, 458-464, http://dx.doi.org/10.1016/j.drugpo.2012.08.001

Horowitz, I.A., Kerr, N.L., Park, E.S. and Gockel, C. (2006). Chaos in the courtroom reconsidered: emotional bias and juror nullification. Law and Human Behavior, 30, 163181, http://dx.doi.org/10.1007/s10979-006-9028-x

Inciardi, J.A. (1977). In search of the class canon: A field study of professional pickpockets, in Weppner, R.S. (ed.) Street Ethnography: Selected Studies of Crime and Drug Use in Natural Settings (pp. 55-78). Beverly Hills, CA: Sage.

Kaplan, C.D., Korf, D. and Sterk, C. (1987). Temporal and social contexts of heroin-using populations: an illustration of the snowball sampling technique. Journal of Mental and Nervous Disorders, 175, 566-574, http://dx.doi.org/10.1097/00005053-198709000-00009 
King, N.J. (1998). Silencing nullification advocacy inside the jury room and outside the courtroom. The University of Chicago Law Review, 65, 433-500, http://dx.doi.org/10.2307/1600227

Lanier, M.M., Henry, S. and Anastasia. D.J.M. (2015). Essential Criminology. (4th Ed). Boulder, CO: Westview Press.

McNamara, R.P. (1994). The Times Square hustler: Male prostitution in New York City. Westport: Praeger.

Miller, W. R. (1991). Moonshiners: Enforcing Federal Liquor Law in the Mountain South, 1865-1900. Chapel Hill, N.C.: The University of North Carolina Press.

Neubauer, D.W. and Fradella, H.F. (2011). America's Courts and the Criminal Justice System $\left(10^{\text {th }}\right.$ Ed.). Belmont, CA: Wadsworth Publishing.

Okrent, D. (2011). Last Call: The Rise and Fall of Prohibition. New York: Scribner Publishing.

Peine, E.K. and Schaft, K.A. (2012). Moonshine, mountaineers, and modernity: Distilling cultural history in the southern Appalachian mountains. Journal of Appalachian studies, 18, 93-112.

Rayburn, O.E. (1957). Moonshine in Arkansas. The Arkansas historical quarterly, 16, 16973), http://dx.doi.org/10.2307/40018450

Riggs Hafley, S. and Tewksbury, R. (1996). Reefer madness in bluegrass country: community structure and roles in the rural Kentucky marijuana industry. Journal of Crime and Justice, 19, 75-94, http://dx.doi.org/10.1080/0735648X.1996.9721530

Ross, H.L. (1973). Folk Crime Revisited. Criminology, 11, 71-85, http://dx.doi.org/10.1111/j.1745-9125.1973.tb00587.x

Ross, H.L. (1960-1961). Traffic Law Violation: A Folk Crime. Social Problems, 8, 231241, http://dx.doi.org/10.2307/798913

Sellin, T. (1938). Culture Conflict and Crime. merican Journal of Sociology, 44, 97-103, http://dx.doi.org/10.1086/217919

Spellman, W.E. and Jorgenson, M.R. (1982). The social and revenue effects of state alcohol beverage control. American Journal of Economics and Sociology, 41, 77-83, http://dx.doi.org/10.1111/j.1536-7150.1982.tb01669.x

Troshynski, E.I. and Blank, J.K. (2008). Sex Trafficking: An Exploratory study interviewing traffickers. Trends in Organized Crime, 11, 30-41, , http://dx.doi.org/10.1007/s12117-0079015-8 
Ullman, C. (2005). D.C. Bar Opinion 320: How a Defense Attorney Can Advocate for Her Client Without Encouraging Jury Nullification. The Georgetown Journal of Legal Ethics, 18, 1097-1109.

Watman, M. (2010). Chasing the White Dog: An Amateur Outlaw's Adventures in Moonshine. New York: Simon \& Schuster.

Weisheit, R.A. (1990). Domestic marijuana growers: Mainstreaming deviance. Deviant Behavior, 11, 107-129, http://dx.doi.org/10.1080/01639625.1990.9967837

Wigginton, E. (Ed.). (1971). The Foxfire Book. Garden City, NY: Anchor Press.

Wilson, M. (1983). Folk crime: Patterns of accommodation. Deviant Behavior, 4, 123-140, http://dx.doi.org/10.1080/01639625.1983.9967607 